\title{
The Relationship between the Existence of Butler and Service Quality received by VIP Guests
}

\author{
Nevie Ariesa Fandya ${ }^{1 *}$, Nurbaeti $^{2}$, Sri Sulartiningrum ${ }^{3}$ \\ 1,2,3 Sekolah Tinggi Pariwisata Trisakti \\ *nevie_ariesa@hotmail.com
}

\begin{abstract}
Good service quality in the hotel can be achieved if employees are able to anticipate and meet the guest's needs. Therefore, it is necessary to have a section focusing on a certain type of guests, namely VIP and VVIP guests. in order to achieve good relations with guests. This section is called Butler which cover personal services so that the service quality is expected to increase. This study aims to study the guests opinion about the existence of Butler at Raffles Hotel, Jakarta and to find out the relationships between Butler and service quality. Research methods used is descriptive correlational where correlational coefficient and coefficient of determination are computed. Data was collected using questionnaire distributed to VIP/VVIP guests at Raffles Hotel Jakarta. Sample size was 53 and sampling technique was non probability purposive sampling. The result showed that on the whole the existence of butler was rated very good by VIP guests in Raffles Hotel Jakarta. Meanwhile, service quality received by guests was also very good. There was a strong positive relationship between Butler's existence and service quality in Raffles Hotel Jakarta.
\end{abstract}

Keywords: butler, service quality, VIP guest 


\section{A. Introduction}

Tourism is an industry that is rapidly evolving from time to time dynamically and interactively. The tourism industry is not affected by the world crisis. Evidenced by the still large number of visitors who travel and business trips, as it is proposed by Arief (2005). As the development of the tourism sector has an impact on the provision of accommodation for tourists as their temporary residence during a tour. The accommodation industry as the main tourism vehicle (main tourism suprastructure) cannot be separated with the tourism industry because they need each other. Arief (2005)

According to Bagyono (2006), the hotel business has special features, namely the combination of tangible product business and selling services (intangible products) such as hospitality, courtesy, speed and convenience provided by the employees. Nowadays, improving the quality of services offered by hotels to the public is increasingly being considered as a tool to achieve competitive advantage and to make guests loyal or likely to attract new guests. Guests visiting the hotel are of different kinds.

According to Della (2008), guests are divided into 3 types namely:, standard guests who booked a standard room or guests who come to the hotel to visit a restaurant or a particular event in a company in the hotel; VIP guests who stay in the suite room, have a high position in a company or stay for a long period of time; VVIP guests who serve as head of state, ambassadors, or international celebrities.

Guests will feel satisfied if the services provided meet their expectations.. Quality of service at the hotel can be achieved if the employees are able to communicate well with the guests. Anticipating and meeting all the needs and wants of the guests, it is necessary to have a section focusing on one type of guest, in this case the VIP and VVIP guests in order to achieve good relations with guests. This section is called Butler. Hotel Raffles is a 5 star hotel located in Jakarta with a special section in the Front Office department called Butler. This section has an important role in the effort to meet the needs and desires of guests. This section provides individualized services or services on the basis of the individual guest (personal services). Therefore, the quality of service is supposed to increase.

According to the preceding paradigm of a section in the Front Office assigned to serve VIP guests is the Guest Relations Office (GRO). A Guest Relations Officer is assigned to check in room (In room check in) and check out in the room (express check out) without the VIP guests queuing up at the reception. According to Agusanwar (2010), as the era progresses, the wishes of guests staying in five star hotels are getting higher where a service must be accompanied by a sense of care from a service to his guest known as Service to Caring then created a department that is Butler. 
According to Ferry (2015) the Butler department was first owned by the Shangri-La Barr Al Jissah Resort and Spa Muscat, Oman. The hotel provides more service to their VIP guests in the presence of Butler, where the appointed Butler for VIP and VVIP guests is on duty for 24 Hours. The response from guests at Shangri-La Barr Al Jissah Resort and Spa Muscat, Oman is memorable with Butler's service. With a tremendous feedback $100 \%$ of his guests commented "the best service they get in all their travels from a Butler". Because this is heard by other 5-star hotel hotels in the middle east area which impacted the hotels of other 5 star hotels following to have founded Butler Department.

Raffles Jakarta hotel history established in 2015, this Hotel has established Butler Department to give individual services to VIP and VVP guests in the hope there is no tone of complaints from guests about the quality of services provided by the hotel. Hotel Raffles is one of the best 5 star hotels in Jakarta, as evidenced by the No. 1 ranking. One on Trip Advisor for 2 years. The high cost of the room in the set to make the guests have hope and desire to get maximum service. Like when guests use and transport from the hotel, they get the facilities IPad, Wi -Fi, candy, cold towel, charging cable, can play favorite music. So not only do they ride the usual transportations but there is a luxury in it accordingly

Based on the introduction, this research was conducted with the following purposes to (1) study the guests opinion about the existence of butler, (2) study service quality, and (3) determine the relationships between the existence of butler and service quality. The existence of Butler was analyzed based on their characteristics: initiative, capability, carefulness, quickness, tolerance, confidence, intelligent, manners, enthusiasm, and knowledgeable. Meanwhile, service quality was analyzed based on 5 dimensions: reliability, responsiveness, assurance, empathy, tangibles

\section{B. Literature Review}

\section{Front Office Department}

Front office is one of the departments in hotel which is operationally connected directly with the guests. The main role and function of the Front Office section is to sell rooms to guests. According to Sulastiyono (2008: 66) Front Office is the control center of hotel activities because this section control the whole process of administration, communication and information related to the guests during their stay at the hotel. Then processed, packaged and presented as a product of hotel services and services.

All guest complaints relating to hotel services, whether complaints related to room service or food and beverage services are always received through Front Office and Front Office will do the first action to overcome the complaints of guests. The Front Office Department has a mission that is vital to the success of the hotel business. Because the product becomes the main revenue (main revenue / income) of the hotel from the room rental.

TRJ Tourism Research Journal, Volume 1 (1), 2017 
The Front Office Department has several sub-sections: Reservation, Concierge, Reception, Guest relations Officer, Butler, Front Office Cashier, Bookkeeper.

\section{Butler}

Butler originally came from the western and central world of Britain. In ancient times until medieval times, the story began from the harsh beverage kept in jugs of clay or wood, and his treatment became a very trustworthy responsibility. From here comes the word "Butler", which is derived from the French bouteilier (slave carrier bottle), and earlier from the Latin with butticula. According to Spruce (2006: 22), the butler is "a male servant and head of the household". Meaning that Butler was a male servant and head of household. Then a few years later a woman also began to become Butler as poured by Ferry (2009: 1), Although unusual, women were also employed as "butleresses". The first female butler on record appears to have been named "Brunch" and she became the best butler in the country. This means that the woman who became Butler named Butleresses and first woman who became Butleresses named Ms. Bunch and he also became the best Butler in the country at the time.

People who are believed to be bottle carriers also do very complex jobs such as maintaining a clean house, taking care of household necessities, establishing the needs of the king or can we say they are the personal ministry of the king. From here the development of bottled carriers believed to take care of the home kingdoms of the ancient western world, the inspiration of the hotelier world who always want to serve but they exclusively. Understanding the butler itself according to Ferry (2009: 11), "A butler is a person who takes on the duties of a valet or personal assistant, organizing his employer's personal and social life, traveling with him or her, acting both as a business secretary and social secretary - in other words ". It means that Butler is someone who takes on the responsibilities of a personal butler, organizes the employees and goes along with the department concerned.

Butler is one of the new section in the field of hospitality, still not many hotels that have Butler because the task of Butler itself is serving the needs of guests from the beginning to come until they get out of the hotel. Users usually only handle VIP guests only or guests staying in the largest room size in the hotel are for example: Suite Room, Presidential Suite, Villa or Royal Suite.

As told by Adams (2005: 89) To be a good butler and qualified, must be able to meet the requirements on requirements that must be owned by a good but good quality Butler: leadership, physical and mental health, carefulness, punctuality, ability to take criticisms, cooperative, personable, knowledgeable, sincerity, interest, attitude the guest, enthusiasm, manners, intelligent, confidence, tolerance, quickness, capability, initiative, willingness to accept direction, appearance, speech, language, memory, loyalty, friendliness, healthy, honesty, aptitude, and resourcefulness.

TRJ Tourism Research Journal, Volume 1 (1), 2017 
There are differences of opinion about Butler itself. Butler was intended to serve VIP guests but the task was still the same as the job of a Guest Relations Officer. They only check-in and check-out also serve special requests from guests such as preparing a surprise birthday or anniversary. Butler who is currently Raffles Jakarta wants to be a Butler of the same job as the United Kingdom, which is to accompany the guests for 24 Hours with their VIP guests to sleep until they fall asleep at night.

\section{Service quality}

Service will have a role in the survival of an organization, because the product without any service that can satisfy the users of the output of profitoriented organizations.

According to Fandy Tjiptono and Gregory Chandra in the book Service, Quality, Satisfaction (2005) quality is "a relative measure of perfection or goodness of a product / service, consisting of design quality and conformity quality". The same thing is also expressed by Garvin and Davis in the book Total Quality Management (2004) which says "Quality is a dynamic condition related to product, human / labor, processes and tasks, and environments that meet or exceed the expectations of customers or consumers".

The existence of these two meanings further reinforces that the quality is sourced to the guest judgment of the product or service consumed, whether it has been in line with expectations or even exceed those expectations. Still from both of these understandings can the authors conclude that a qualified company is able to meet expectations or exceed the expectations of guests who consume goods or services produced.

The emergence of satisfaction can be due to the quality of service, satisfied because of the timeliness, satisfaction because of the price, satisfied because of the hospitality, and satisfied by the warm welcome on arrival. Satisfaction of guests or customers is based on experience and expectations (service encounter)

Service is essentially all economic activity that is the result product in physical form or construction, which is usually consumed at the same time with the time generated and provide added value (such as convenience, entertainment, pleasure or health) or is a solving on the problems faced by consumers and can provide customer satisfaction. In addition, in the service there is interaction between the consumer and service providers.

After discussing the quality and the next product will be discussed a little about the service (service). According to Zeithaml and Bitner in the book Service Marketing (2003: 3) the definition of service is: "Service are deeds, processes, and performance". This brief understanding illustrates that service is a comprehensive outcome, process and performance.

The measure of service quality is a relative matter of a customer satisfying or dissatisfied with the service it receives depends on the things that form the 
basis for them to determine whether the results received in accordance with expectations or not. In general, customers consider some things as a benchmark in making decisions on service received.

According to Tjiptono and Chandra quoted from the study originally Parasuraman, et al. in the book Service, Quality, Satisfaction identify the existence of ten basic dimensions in service quality that is tangibles, reliable, responsive, competence, courtesy, credibility, security, access, communication, understanding the customer. However, in the next study, these experts purify the dimensions of service quality into five dimensions, where competence, courtesy, credibility, security are incorporated into assurance, while access, communication, understanding the customer are categorized as empathy. Thus, there are 5 (five) main dimensions, namely:

\section{Reliability (reliability)}

Reliability is the ability to deliver promised services appropriately and reliably. In a broad sense, reliability means the company's ability to keep its promises, service provisions, breakdowns and pricing. Customers will only transact with companies that keep their promises, especially about the service on the core product.

\section{Responsiveness (quick response)}

Quick response is a willingness to help to help customers and to provide prompt and precise services. Quick response emphasizes attention and speed in serving requests, complaint questions and customer issues. There is one action in which we give something according to the wishes of the guests. To provide responsive service, companies must be confident in viewing the service process and handling requests from a customer's point of view rather than the company's own point of view.

\section{Assurance (guarantee)}

Guarantees are the knowledge of employees and their hospitality and the ability of companies with their employees to inspire the trust that customers provide. In other words, guarantees are an attempt to form trusting relationships between customers and companies. The company gives entrusted names and competent employees, otherwise customers will give their loyalty to the company, for example: they will be regular guests or they can be a good promotion to friends, family or business relatives.

4. Empathy (empathy)

Empathy means the presence of caring, individualized attention by the company to the customer. The essence of empathy is the delivery of caring and corporate attention through professional service to show that the customer is 
unique and special for the company through anticipation of providing for the needs of the customer before they ask for it.

5. Tangibles (tangible product)

Tangible products represent physical services in the form of facilities, employee tools, and marriage communications

\section{Research Methods}

The research method used is descriptive correlational to describe the relationship between two variables under study. The first variable is butlers' characteristics as independent variable, and the second variable is service quality as a dependent variable. Below is the table of variable, sub variable, and scales.

Tabel 1. Variabel, Sub variable \& Measurement Scale

\begin{tabular}{llll}
\hline No & \multicolumn{2}{c}{ Variable } & \multicolumn{1}{c}{ Measurement Scale } \\
\hline 1 & Butler & 1. Initiative & Likert Scale \\
& 2. Carefulness & 1. Strongly disagree \\
& 3. Capability & 2. Disagree \\
& 4. Quickness & 3. Neutral \\
& 5. Tolerance & 4. Agree \\
& 6. Confidence & 5. Strongly agree \\
& 7. Intelligent & \\
& 8. Manner & \\
& 9. Enthusiasm & \\
& 10. Knowledgeable & \\
& & \\
\hline 2 & 1. Reliability & Likert Scale \\
& 2. Responsiveness & 1. Strongly disagree \\
& 3. Assurance & 2. Disagree \\
& 4. Empathy & 3. Neutral \\
& 5. Tangible & 4. Agree \\
& & 5. Strongly agree
\end{tabular}

Research instrument to collect data is a questionnaire distributed to customers of Hotel Raffles, South Jakarta. The questionnaire consists of some statements to measure butler's characteristics and service quality. Then mean value of each statement in the questionnaire is calculated and categorized as follows. 
Tabel 2. The Interpretation of Mean value

\begin{tabular}{cc}
\hline Mean Value & Meaning \\
\hline $1-1.74$ & Very Low / very poor \\
$1.75-2.49$ & Low/ poor \\
$2.50-3.24$ & Neutral \\
$3.50-4.24$ & High/ good \\
$4.50-5.00$ & Very high/ very good \\
\hline
\end{tabular}

The population in this research is customers of Hotel Raffles Jakarta. The sampling technique is non-probability purposive sampling where the customers may not necessarily have the same opportunity to be selected as a sample and there is certain consideration in selecting a sample based on the purpose of the research (Narbuko and Ahmadi 2009:45). The sample size is 53 respondents.

The data collected was analyzed by calculating correlation coefficient and coefficient determination to find the relationship between butler's characteristics and service quality, and the extent to which butler characteristics influence service quality given to VIP guests at Raffles Hotel, Jakarta.

This research was conducted in Hotel Raffles, South Jakarta included the following activities: In - depth interviews conducted from 10 January 2017 - 14 February 2017, focus group discussion held on 10 January 2017 at Hotel Raffles Jakarta in order to explore and capture the actual situation about the Butler service and the Quality Services in Hotel Raffles Jakarta and questionnaire distribution followed by data analysis from Mei 2017 - 10 Juni 2017.

\section{Result and Discussion}

Hotel Raffles Jakarta, is a new hotel which was established on March 16, 2015. The owner is Ir. Ciputra. a.k.a. Tjipoetra or Tjie Tjin Hoan who was born on August 24, 1931 as a Chinese entrepreneur who has Ciputra Development Indonesia, property in Indonesia, and Group of Ciputra. Born in Parigi, Central Sulawesi, Ciputra is the 23rd richest person in Indonesia according to Forbes, with total assets owned 1.3 billion US dollars and is also the successful business man in Indonesia.

The first Hotel Raffles was established in 1887 in Singapore. This first hotel is still operating. In 2014, Raffles opened its property in Istanbul. In 2015, Jakarta is selected as the next city to open the next branch.

In Singapore, Raffles is legendary thanks to its history. For its branch in Jakarta, this brand also intends to revive history, but the medium is not old buildings, but old paintings. Exactly the old paintings of Hendra Gunawan's favorite Ciputra.

In Jakarta, Raffles is working with a renowned collector to give an artistic hotel that blends luxury with art. The interior features a distinctive design dedicated to the memory of Hendra, the founder of the Indonesian Academy of 
Fine Arts. Massive mosaic painting are on display in the hotel lobby. While the work titled Arjuna Breastfeed adorning the walls of the Writers Bar. A stop at the Arts Café, featuring a Durian Traders who enrich the atmosphere of the meal. "Every art object is selected directly by Mr. Ciputra himself," said Viana Igah, Director of Marketing Communications. "Everything has meaning and story." Raffles Jakarta has 173 rooms. Each unit also did not escape the touch of Hendra. In the bathroom for example, a replica of Biting Crab beautifies the wall and ignite the imagination. The work of 1970 is indeed very liked Ciputra. If you want more in knowing Hendra, Raffles Jakarta has prepared Art Concierge. The Ciputra Museum is directly connected to the hotel. You can also find sketches and personal letters from Hendra Gunawan.

This premium inn comes with an impressive selection of food outlets, the Writers Bar (all over Raffles properties), the Arts Café and the poolside Navina. The management plan to open two other restaurants in the near future. The hotel, which opened on March 16, 2015 also provides a variety of meeting room options ranging from private boardroom to ballroom area of 2500 square meters. Other facilities include a swimming pool, tennis court, fitness center, yoga area, and a 300-meter jogging track garden ocated on the 14th floor.

Hotel raffles Jakarta in 2015 has gained the trust of the local government to provide services to the King of Saudi Arabia and several other heads of state who are visiting Indonesia. After 6 months the Hotel Raffles Jakarta has reached its position No. 1 on TripAdvisor and this proves that the service given by this hotel is well enough to be chosen by important guests. As to what distinguishes this hotel from other hotels is the 24-hour Butler Services offered to VIP and VVIP guests staying at this hotel. This also makes the reason why the local government chose Hotel Raffles Jakarta as a hotel that has good credibility.

Tabel 3. Characteristics of Respondents according to Nationality

\begin{tabular}{ccc}
\hline Nationality & Number & $\%$ \\
\hline Asian & 13 & $25 \%$ \\
Europian & 21 & $40 \%$ \\
Arabic & 12 & $23 \%$ \\
African & 7 & $13 \%$ \\
\hline Total & 53 & $100 \%$ \\
\hline
\end{tabular}

Table 4 depicted that there are $25 \%$ respondents who are Asian citizens, $40 \%$ European, 23\% Arabic, 13\% Africans. Therefore, the biggest percentage is dominated by European respondents. Due to VIP guests of Raffles Jakarta who come for business trip is dominated using corporate rate with foreign companies from Europe, such as L'Oreal. 
Table 4. Characteristics of Respondents according to Gender

\begin{tabular}{ccc}
\hline Gender & Number & $\%$ \\
\hline Male & 37 & $70 \%$ \\
Female & 16 & $30 \%$ \\
\hline Total & 53 & $100 \%$
\end{tabular}

Based on table 5 it can be seen that $70 \%$ respondents are male and $30 \%$ are female. It can be concluded that the number of male guests staying at Raffles Hotel, Jakarta, is bigger than female. This is because the businessmen who come to Hotel Raffles Jakarta is dominated by men who have high positions in their company.

Table 5. Characteristics of Respondents according to Age

\begin{tabular}{ccc}
\hline Age & Number & $\%$ \\
\hline $20-29$ & 13 & $25 \%$ \\
$30-39$ & 30 & $57 \%$ \\
$40-49$ & 7 & $13 \%$ \\
$>50$ & 3 & $6 \%$ \\
\hline Total & 53 & $100 \%$ \\
\hline
\end{tabular}

Based on Table 5 it can be seen that $25 \%$ of respondents are $20-29$ years old, $57 \%$ are $30-39$ years old, $13 \%$ are $40-49$ years old, and $6 \%$ are over 50 years old. So the largest percentage based on age is dominated by the age of 30-39 years. This is because the age of 30-39 is the productive age for the businessmen with the position as $\mathrm{CEO}$, or as head of the royalty

Table 6. Characteristics of Respondents according to Marital Status

\begin{tabular}{ccc}
\hline Status & Number & $\%$ \\
\hline Single & 25 & $47 \%$ \\
Married & 28 & $53 \%$ \\
\hline Total & 53 & $100 \%$ \\
\hline
\end{tabular}

Based on Table 6 above can be seen that based on unmarried respondents of $47 \%$ and married respondents of $53 \%$. So the married respondents' greater percentage compared with the married. This is in because with the age of 30-39 years with a well-established life they already have an average family. 
Tabel 7. Characteristics of Respondents according to Education backgroud

\begin{tabular}{ccc}
\hline Education & Number & $\%$ \\
\hline Bachelor & 10 & $19 \%$ \\
Diploma & 13 & $25 \%$ \\
Master & 17 & $32 \%$ \\
Doctor & 6 & $11 \%$ \\
Professor & 7 & $13 \%$ \\
\hline Total & 53 & $100 \%$ \\
\hline
\end{tabular}

Based on Table 7 above it can be seen that 19\% respondents who have high school education, 25\% have Diploma degree, 32\% have Master's degree (S2), 11\% have doctoral degree, and 13\% entitled Professor. Thus the respondent who has the largest percentage is the master (S2). This is because a leader in a company must have higher education, at least Master degree or (S2).

Tabel 8. Characteristics of Respondents according to Salary

\begin{tabular}{ccc}
\hline Salary & Number & $\%$ \\
\hline $1000-3000$ USD & 8 & $15 \%$ \\
$3001-7000$ USD & 16 & $30 \%$ \\
$7001-11000 U S D$ & 16 & $30 \%$ \\
$>11001$ & 13 & $25 \%$ \\
\hline Total & 53 & $100 \%$ \\
\hline
\end{tabular}

Table 8 showed that $15 \%$ of respondents have a salary between $1000-3000$ USD, $30 \%$ between $3001-7000$ USD, 30\% between 7001-11000 USD and 25\% more than 11000 USD. This is not surprising because most of respondents have a high job position in their company which should be in line with their high enough salary.

Table 9. Reasons to stay at Raffles Hotel, Jakarta

\begin{tabular}{ccc}
\hline Reason to stay at Raffles & Number & $\%$ \\
\hline Business & 22 & $42 \%$ \\
Holiday & 15 & $28 \%$ \\
Family Visit & 13 & $25 \%$ \\
Healthy Reason & 3 & $6 \%$ \\
\hline Total & 53 & $100 \%$ \\
\hline
\end{tabular}

Table 9 showed that $42 \%$ of respondents stay in Raffles Hotel for business, $28 \%$ for holiday, 25\% for family visit, and $6 \%$ for health reason (visit good hospitals and doctors in Jakarta). In other words, the majority of respondents stay in Raffles Hotel Jakarta for work. 
Table 10. Mean value of Butlers' characteristics.

\begin{tabular}{cccc}
\hline \multicolumn{4}{l}{ Item Statistics } \\
\hline & Mean & Std. Deviation & $\mathrm{N}$ \\
Initiative & 4.6604 & .51677 & 53 \\
Carefulness & 4.6415 & .48415 & 53 \\
Capability & 4.5849 & .53472 & 53 \\
Quickness & 4.0755 & .87374 & 53 \\
Tolerance & 4.7358 & .44510 & 53 \\
Confidence & 4.6226 & .56249 & 53 \\
Intelligence & 4.6415 & .52236 & 53 \\
Manners & 4.6226 & .48936 & 53 \\
Enthusiasm & 4.6038 & .56635 & 53 \\
Knowledge & 4.5849 & .63349 & 53 \\
Overall & 4.5773 & & \\
\hline
\end{tabular}

Table 10 showed that in general Butler's characteristics was very good because overall the mean score was 4.5773 . The highest mean score was 4.7358 for their tolerance, while the lowest score was 4.0755 for their quickness. It means the guests were very satisfied with Butler's tolerance when serving the guests. On the other hand, butler's quickness in serving the guests, needed to be improved because the score was not as good as other characteristics.

Table 11. Service Quality Descriptive Statistic

\begin{tabular}{cccc}
\hline \multicolumn{4}{l}{ Item Statistics } \\
\hline & Mean & Std. Deviation & $\mathrm{N}$ \\
\hline Reliability & 4.8113 & .44100 & 53 \\
Responsiveness & 4.9811 & .13736 & 53 \\
Assurance & 4.8868 & .31988 & 53 \\
Empathy & 4.9623 & .19238 & 53 \\
Tangibles & 4.6226 & .56249 & 53 \\
Overall & 4.8528 & & \\
\hline
\end{tabular}

Based on Table 11, service quality at Raffles Hotel was categorized very good with the overall mean score 4.8528. The highest dimension of service quality was empathy with the mean score of 4.9623 , while the lowest dimension was tangible with the mean score of 4.6226. The guests seemed to be very satisfied with the empathy showed by butlers when serving them. For the improvement, butlers could pay attention to the tangibles factors such as uniform or physical facilities. 
Table 12. Correlation between Butler and Service Quality

\begin{tabular}{cccccc}
\hline \multicolumn{5}{c}{ Correlation } \\
\hline & Reliability & Responsiveness & Assurance & Empathy & Tangibles \\
\hline Initiative & -0.061 & 0.225 & 0.170 & -0.103 & 0.307 \\
Carefulness & -0.033 & 0.516 & 0.358 & 0.329 & 0.439 \\
Capability & -0.142 & 0.300 & 0.327 & -0.089 & 0.188 \\
Quickness & -0.007 & 0.514 & 0.286 & 0.110 & 0.111 \\
Tolerance & -0.123 & 0.332 & 0.554 & 0.347 & 0.479 \\
Confidence & 0.177 & -0.125 & -0.006 & 0.095 & 0.153 \\
Intelligence & 0,120 & 0.541 & 0.406 & 0.324 & 0.233 \\
Manners & -0.073 & 0.328 & 0.691 & 0.338 & 0.468 \\
Enthusiasm & -0.009 & 0.516 & 0.433 & 0.441 & 0.659 \\
Knowledgeable & 0.111 & 0.397 & 0.379 & 0.239 & 0.269 \\
\hline
\end{tabular}

Table 12 showed correlation between 10 characteristics of butler and 5 dimensions of service quality. It can be seen that there is a negative correlation between initiative and reliability. It indicates that if the values for initiative increases, values for reliability decrease and vise versa. The same condition also happened between initiative and empathy. On the other hand, Initiative has a positive correlation with responsiveness, assurance and tangible which indicates that if the values for initiative from the butler increase, responsiveness, assurance and tangibility of service quality also increase.

Regarding butler's carefulness, the data showed that there is a negative correlation between carefulness and reliability. On the other hand, there is a positive correlation between butler's carefulness and responsiveness, assurance, empathy and tangible. The highest correlation was between carefulness and responsiveness (0.516).

Meanwhile, butler's capability has a negative correlation with reliability in service quality. It means when the value of capability increase, the reliability decrease. On the other hand, capability has a positive correlation with responsiveness, assurance, empathy and tangibles. It means when capability increases, then responsiveness, assurance, empathy and tangibles will also increase. The highest correlation is between capability and assurance

Regarding the quickness of the butler, there is a negative correlation between the quickness and reliability in service quality. On the other hand there is a positive correlation between quickness and responsiveness, assurance, empathy, and tangible. The highest positive correlation is found between quickness and responsiveness.

Like quickness, tolerance has a negative correlation with reliability and positive correlation with other dimensions of service quality, namely responsiveness, assurance, empathy and tangibles. The highest positive correlation is between tolerance and assurance. I means when the value of tolerance in butler's characteristic increases, the assurance also increases. 
Unlike tolerance, confidence has a positive correlation with reliability and negative correlation with responsiveness and assurance. Confidence also has positive correlation with empathy and tangibles. It means when confidence increases, responsiveness and assurance decrease. On the other hand, if confidence increases, reliability, empathy and tangible also increase and vise versa.

Unlike other characteristics of butler which has been discussed, intelligence has positive correlation with all dimensions of service quality, namely reliability, responsiveness, assurance, empathy and tangibles. The highest positive correlation is between intelligence and responsiveness.

Regarding manners, this characteristic has a negative correlation with reliability. On the other hand, manners has a positive correlation with other dimensions of service quality, namely responsiveness, assurance, empathy and tangible. Manners has the strongest positive correlation with assurance. It means when the value of manner increases, the value of assurance also strongly increase.

Like manners, enthusiasm has negative correlation with reliability and positive correlation with other dimensions of service quality, namely responsiveness, assurance, empathy and tangibles. Unlike manners, the strongest positive correlation was found between enthusiasm and tangibles.

Finally, knowledge has positive correlation with all dimensions of service quality, namely reliability, responsiveness, assurance, empathy and tangibles. The highest correlation was between knowledge and responsiveness. It means when butler's knowledge increase the value of responsiveness will also increase.

Tabel 13. Correlation Coefficient between s Butler and Service Quality.

\begin{tabular}{|c|c|c|c|}
\hline \multicolumn{4}{|c|}{ Correlation } \\
\hline \multirow{6}{*}{ Butler } & & Butler & Service \\
\hline & & & Quality \\
\hline & Pearson & 1 & .732 \\
\hline & Correlation & & \\
\hline & Sig. (2.tailed) & & .000 \\
\hline & $\mathrm{N}$ & 53 & 53 \\
\hline \multirow{4}{*}{$\begin{array}{l}\text { Service } \\
\text { Quality }\end{array}$} & Pearson & -.732 & 1 \\
\hline & Correlation & & \\
\hline & Sig. (2.tailed) & .000 & \\
\hline & $\mathrm{N}$ & 53 & 53 \\
\hline
\end{tabular}

According to Table 13, it can be concluded that there is a strong relationship between butler and service quality because the correlation value is 0.732. We can conclude that when butler's characteristic values increase, service 
quality values received by VIP guests will also increase. This is consistent with the circumstances in which butler provides 24-hour service to the guests.

The coefficient of determination and the relationship between Butler and the quality of service derived from the formula below:

$\mathrm{Kd}=\mathrm{r} 2 \times 100 \%$

$\mathrm{Kd}=(0.0732) 2 \times 100 \%$

$\mathrm{Kd}=53.5824 \%$

Coefficient of determination denotes the strength of the linear association between butler service and service quality. The result showed that 53,58\% of the total variation in service quality can be explained by the linear relationship between butler and service quality. The other $46.42 \%$ of the total variation in service quality remains unexplained.

\section{E. Conclusion}

Based on data analysis, it can be concluded that on the whole butler characteristics in terms of initiative, carefulness, capability, quickness, tolerance, confidence, intelligence, manners, enthusiasm and knowledge are considered very good by VIP guests in Raffles Hotel Jakarta with mean score of 4. 577. The highest score is tolerance and the lowest is tangible factor. Meanwhile, service quality received by guests is also very good with mean score of 4.85. Among five dimensions of service quality under study, responsiveness gets the highest score and tangible has the lowest score.

There is a strong positive relationship between Butler's existence and service quality in Raffles Hotel Jakarta, with correlation value of 0.732 . It can be concluded that the influence of Butler's existence on the quality of service is very significant. Butler can affect the service quality in Raffles Hotel Jakarta for $53.5824 \%$ while the remain $46.4176 \%$ are affected by other factors beyond this research, such as receptionist and other departments sector.

\section{F. Acknowledgement}

This research would not have been made possible without the support of the Management and colleagues in the Hotel Raffles Jakarta. I am also very thankful to the VIP guests of Hotel raffles Jakarta who were willing to participate in the surveys.

\section{REFERENCES}

Abdul Rachman Arief, (2005). Pengantar Ilmu Perhotelan dan restoran. Yogyakarta: Graha Ilmu.

Adams, (2005). Guide Book Man. Singapore: United Book.

Agusanwar. (2004). Resepsionis Hotel. Jakarta: PT. Gramedia Pustaka Utama,

TRJ Tourism Research Journal, Volume 1 (1), 2017 
Bagiyono. (2008). Teori dan Praktek Hotel Front Office. Bandung: ALFABETA.

Bitner, dan Zeithalm. (2003). Service Marketing, Integrating Customer Focus Across the Firm. New York: Mc Graw Hill.

Della, S. (2008). Cara Praktis untuk Pengembangan Profesionalisme di Bidang Management Perhotelan. Jakarta: PT. Bumi Kasara.

Ferry. (2009). British Butler. North Carolina: Greeve Company.

Kusmayadi. (2002). Statistik pariwisata. Jakarta: PT. Gramedia Pustaka Utama.

Kusmayadi \& Endar Sugiarto. (2000). Metodologi Penelitian dalam Bidang Kepariwisataan. Jakarta: PT. Gramedia Pustaka Utama,

Narbuko, Cholid dan Abu Ahmadi. (2009). Metodologi Penelitian. Jakarta: PT. Bumi Aksara.

Richard, Garvin dan Lord Davis. (2004). Total Qulity Management. Jakarta: Yayasan Obor Indonesia.

Sambodo, Agus dan Bagiyono. (2006). Dasar-dasar Kantor depan. Yogyakarta: ANDI,

Spruce, Pamela. (2006). Butler training School. Australia: The Bureu.

Sugiyono. (2009). Metodologi Penelitian Administrasi. Yogyakarta: BPFE Gama.

Sulastiyono, Agus. (2001). Manajemen Penyelenggaraan Hotel,2nd edition. Bandung: ALFABETA.

Tjiptono, Fandy \& Gregorius Chandra. (2007). Service, Quality \& Satisfaction. Yogyakarta: ANDI

Tarmoezi, Trizno \& Heldin Manurung. (2004). Proffesional Hotel Front Liner. Jakarta: Penerbit PT. Gramedia Pustaka Utama.

Umar, Husein. (2000). Riset Pemasaran \& Perilaku Konsumen. Jakarta: Penerbit PT. Gramedia Pustaka Utama. 